\title{
Why do The Auditor Blame for Financial Fraud?
}

\author{
Triyanto ${ }^{1}$, Nafsiah Mohamed $^{2}$, Azizah Abdullah ${ }^{3}$, Gugus Irianto ${ }^{4}$ \\ \{rianto.suwito@gmail.com ${ }^{1}$,nafsiah793@salam.uitm.edu.my², aziza588@salam.uitm.edu.my ${ }^{3}$, \\ gugusit@ub.ac.id $\left.{ }^{4}\right\}$
}

Trisakti University ${ }^{1}$, Accounting Research Institute of Universiti Teknologi MARA ${ }^{2}$, Faculty of Accountancy of Universiti Teknologi MARA ${ }^{3}$, Brawijaya University $^{4}$

\begin{abstract}
The amount of litigation against auditors were negligent increased significantly in recent years. The first aim of this study was to describe the various phenomena of fraud involving the auditor. Second, describe the roles and responsibilities of auditors and legal requirements as a form of auditor liability in Indonesia. Third, presents a variety of risks and the complexity of the task of the auditor. Fourth, this study aims to describe the auditor's responsibility for negligence accomplishments. This study design using qualitative methods. The study was conducted with data derived from literature review, consist of journal and research report that published in internet. The results of this study indicate that auditor must be give pay attention of their roles and responsibilities for their job results. In addition, auditor should be follow the rule of audit regulation.
\end{abstract}

Keywords: fraud, fraud motivation, responsibility auditor

\section{Introduction}

Each company must have financial statements that are beneficial to the company's external and internal. The financial statements will be useful to investors, creditors, governments, and stakeholders in decision-making. Obligations of the financial statements contained in (Bapepam No. Kep-36 / PM / 2003, nd) and (Jakarta Stock Exchange Regulation No. Kep-306 / BEJ / 07-2004), both the regulations specified that the companies listed on the Stock Exchange is required to submit financial statements in accordance with Financial Accounting Standards (GAAP) and audited by an external auditor. The financial statements can be said to be reliable, relevant, and accurate one of them for their roles in the independent external auditors perform an audit.

ACFE (2018) revealed that in 2017 there were 2,690 cases of fraud with a total loss of $\$ 7$ billion. Financial statement fraud schemes (FFR) is a type of fraud most common at $10 \%$ of cases with an average loss of $\$ 800,000$ (ACFE, 2018), Fraudulent Financial Reporting (FFR) is a scheme to represent the financial statements were inappropriate (Kanapickiene \& Grundiene, 2015). After the accounting scandals in the early 2000s such as Enron, WorldCom, and Xerox, the International Federation of Accountants Committee (IFAC) released the International Standard on Auditing 240 on Auditor's Responsibilities Related to Fraud in an Audit Report Keuangan (ISA 240). ISA 240 requires the auditor to learn about the conditions that increase the risk of fraudulent financial reporting to help them develop the program more effective audit tests (Mubako \& O'Donnell, 2018). IFAC (2009) explains the purpose of ISA 240: (a) to identify and assess the risks of material misstatement of the financial statements due to fraud; (B) to obtain sufficient audit evidence about the risks.

Accounting and auditing have been developed to prevent asset misappropriation and misrepresentation in the financial statements (Yiu, Xu, \& Wan, 2014). Audits carried out to eliminate the asymmetry of information (Asongu, Nwachukwu, and Tchamyou, 2016), in which management as preparers of financial statements have more information than others, so that both the makers and users of financial statements would have the same understanding of the financial statements (Asongu et al., 2016). In addition, the audit also to ensure accountability and corporate management. (Halbouni, 2015; Stirbu, Moraru, Farcane, Blidisel, and Popa, 2009).

Audit make financial statements more reliable and relevant as one of the tools for making economic decisions for stakeholders (Topor, 2017). On the other hand, according to Chau and Yuen (2011) in Halbouni (2015) said that users of financial statements assume that the main purpose of the 
audit is to detect fraud. However, the confidence gained by an auditor is subjective and serve as a basis to offer audit opinion. The auditor can not achieve absolute assurance when there is limited evidence of the audit, inherent risk and uncertainty.

This manuscript is a conceptual paper that aims to first. describe a variety of phenomena involving fraud auditors. Second, describe the roles and responsibilities of auditors and legal requirements as a form of auditor liability in Indonesia. The third presents a variety of risks and the complexity of the task of the auditor. The fourth paper describes the auditor's responsibilities for negligence accomplishments.

This paper begins with the first part, which consists of the introduction and research purposes. The second part contains berbaga phenomenon of fraud involving the auditor, followed by a third part contains research methods. The fourth part of the paper shows the results of the study. Furthermore, the final part of this manuscript are the conclusions and suggestions for professional auditor and auditor professional institutions in Indonesia.

\section{Literature Review}

\subsection{Phenomenon of Fraud}

In early March 2017, the SEC published an official announcement about the allegations of fraudulent practices to the Mexican housing development company that is Desarrolladora Homex SAB de CV (Homex). Homex recognizes proved fictitious sales of 100,000 units during the three years of financial reporting by $355 \%$ or US $\$ 3.3$ billion (2009-2011). Based on the investigation of fraud, it is evident that most of the land there is no grounding work and buildings that are considered sold has remained undeveloped. Homex obtained sanction is suspension of stock trading and the prohibition for Homex to sell new shares in the United States for five years (Priantara, 2017),

Another fraud case in the world was a financial scandal American Insurance Group (AIG) in 2005. This fraud came to light when federal agencies and US states begin an investigation after receiving a report. The results of an investigation found massive accounting fraud even up to nearly $\$ 4$ billion. The company must settle with the SEC and the pension funds of the two countries amounted to more than $\$ 2$ billion. AIG plays an important role in the financial crisis of 2008 in the United States rather than affecting almost all of Western Europe and parts of Asia.

In Indonesia, cases of fraud that have occurred are PT Bank Bukopin Tbk (BBKP) revising the financial statements last three years, namely 2015, 2016 and 2017. The Financial Services Authority (FSA) also perform checks. Based on information compiled by CNBC Indonesia, fraud in the form of credit card data modifications and has performed more than five years ago. The modification causes the position-based credit and commission income increased by an amount Bukopin improperly. Interestingly, this incident escaped from the internal audit Bukopin, Public Accounting Firm (KAP) as an independent auditor, Bank Indonesia as the authority of the credit card payment system, as well as the FSA as a banking supervision agency(Lewis, 2018),

Financial Services Authority (FSA) imposed an administrative sanction in the form of cancellation of registration and ban adds new clients in the sector of Banking, Capital Markets and IKNB to Public Accounting Firm (KAP) Deloitte. These sanctions related unqualified opinion on the Annual Financial Statements PT Sunprima Nusantara Finance (PT SNP). PT SNP indicated to have presented financial statements that do not correspond to the actual conditions and used to obtain cre dit and thus potentially in default or become non-performing loans (FSA, 2018).

The last case that happened to the public accounting firm was what happened to $\mathrm{PwC}$ and its partner, Nicholas Boden. Public accounting firms agree that they do not meet expected standards and fail according to the basic professional principles set by the Institute of Chartered Accountants in England and Wales (ICAEW). Errors that were accepted included failing to obtain appropriate audit evidence and failing to exercise adequate professional skepticism. The number of cases of fraud that befell a number of companies and ultimately also have an impact on the company's public accounting firm, has made fears of legal obligations for auditors continue to grow. Auditors are very important parties, because ultimately they are responsible for improving the reliability of financial statements.

\subsection{Motivation of Fraud}

Triangle fraud is a model to explain the factors that cause a person to commit fraud (Huang, Lin, Chiu, \& Yen, 2016), When fraud exist, a person will be exposed to pressures that drive the action of fraud 
such as financial need. The second factor that drives the action of frauding are conditions that are conducive to providing opportunities for fraud perpetrators. Culture of fraud committed hereditary cause to justify the actions taken, is called rationalization.

Pressure provide the motivation to commit fraud (Free, 2015), Pressure is categorized as financial pressures, vices, work-related stress, and other stresses such as the desire to have more material as their colleagues richer (Dellaportas, 2013), Financial problems are key factors in encouraging fraud action (Hogan, Rezaee, Riley, \& Velury 2008), Financial problems arise as a result of greed, the business in question, the investment failed, or personal financial problems. Vices are divided into action as gambling, drugs, or alcohol that drives someone to do kecuragan. The dissatisfaction with the work, recognition of low performance, fear of job loss, and felt slighted be pressure to commit fraud related to work

Opportunities are conditions or situations that allow a person to commit fraud (Huang, Lin, Chiu, \& Yen, 2016), Opportunities to commit fraud, concealment, and avoid penalties is an important element both in the fraud triangle (Dellaportas, 2013), Internal control systems are less effective provide an opportunity for management to manipulate reported earnings. Failure of performance quality assessment, failure to discipline the perpetrators of fraud, the lack of access to information, lack of audit trail, and ignorance, apathy, or an inability to detect fraud is also an opportunity fraud.

Rationalization is an attitude which allows individuals to commit fraud or ability to rationalize the fraudulent action undertaken (Othman, Aris, Mardziyah, Zainan, and Amin, 2015), In this third category, the perpetrator recognizes that this is wrong, but denied that it was wrong while continuing to be involved in criminal activity (Dellaportas, 2013), Some common forms disclosed rationalization fraud perpetrator is I just borrow money and will return soon, such action will not hurt anyone, this action has a good purpose, organizations do not have a good internal control so I just want to show it, and so forth (Dellaportas, 2013).

\section{Roles and Responsibilities of Auditors}

In 1895, after the Krüger case, in 1944, the role of the auditor underwent major changes. The next auditor's responsibility was expanded to include responsibility for damage to third parties. Auditors who intentionally or unintentionally, directly or indirectly, cause damage to the company must compensate for the damage (Burton et al., 2013). Auditors have responsibilities both internal and external, internal responsibility is the responsibility of the company and external responsibility is the responsibility of the third party (Lindgren \& Lundgren, 2016).

Based on the SA Section 110, the auditor is responsible to plan and perform the audit to obtain reasonable assurance about whether the financial statements are free from material misstatement, whether caused by error or fraud (Lau \& Ooi, 2016). The quality audit referred to is something that requires or liability to encourage auditors behave in accordance with professional ethics (code of conduct). The code of conduct is the norm and principle accepted by a particular group as the basis of the size of the behavior(Burton, Wilks, and Zimbelman, 2013).

Professional conduct of auditors which have been established by the AICPA, including: (a) The principles include responsibility, to act in the public interest, act honestly, integrity, objectivity, and independence, work carefully, and to evaluate the feasibility of the scope and nature of the services, (b) Perturan yanghrus behavior observed by the public accounting profession, (c) Interpretation, (d) completeness of ethics. Meanwhile, according to SPAP (2001) 100 AEs include independence, integrity and objectivity. Professional behavior that is implied in the SPAP requires the auditor should have an independent attitude in carrying out any work and objectivity which are an assurance on quality in delivering value to auditors (Lindgren \& Lundgren, 2016).

At the end of each fiscal year, the auditors submit the audit report to the board of directors. The audit report isreportauditorwhich states thatexaminationcarried out in accordance with the norms of inspection accountant. Accompanied by an opinion on the fairnessreportfinancecompanychecked. The auditor's opinion is divided into unqualified, a qualified, unnatural, and refused to give an opinion (Lisic, Silveri, Song, \& Wang, 2015). Statements in the report should determine whether the annual report reflects a true and fair view of the results and financial position of the company, and whether the report contains material errors.

The purpose of the audit report is to add credibility to the financial statements (Lindgren \& Lundgren, 2016). The audit report is the only public report submitted by the auditors and also is the only 
relationship between the auditor and the company's stakeholders about the results of the audit. The audit report should serve the public interest and adds credibility to the financial statements of the company, but on the other hand it does not mean that investors and other stakeholders can ignore other information from the company and did not make their own opinion (DeZoort \& Harrison, 2018). The annual report and audit report serves as the basis for decision making.

\section{Risk and Complexity of Liability of Auditors}

Samsonova-Taddei \& Humphrey (2014) conceptualizes responsibility as a source of risk. Hilgartner characterize risk not as a static fact, independent of interpretation, but as an entity that contextual meanings vary and are inherently unstable. Differences in how we conceptualise risk stems from the risky way of defining objects and identify them by establishing a causal link between the object with the alleged damage.

In the case of the auditor's responsibilities, the key dimensions of variation in the understanding of the risks associated with the liability of auditors revolve around questions such as: who and under what conditions have to bear the consequences of liability claims as well as who the injured party and has the right to demand compensation for damages related. Each party has relied on the audit opinion can claim damages against the auditor arising from misstatement (Samsonova-Taddei \& Humphrey, 2014). It is considered as an appropriate way to discipline auditors and also respond to public calls for fair treatment against innocent third parties such as potential investors, creditors, employees and other stakeholders (Chung, Farrar, Puri, \& L. Thorne, 2010).

\section{Personal Liability For Damages}

In 1895, the auditor is responsible to compensate the damage caused by the company for negligence in the audit (Lindgren \& Lundgren, 2016). After the accident Krüger, in 1944, the role of the auditor underwent major changes. The next auditor's responsibility was expanded to include responsibility for damage to third parties. Auditors who intentionally or unintentionally, directly or indirectly, cause damage to the company must compensate for the damage (Burton et al., 2013). Auditors have responsibilities both internal and external, internal responsibility is the responsibility of the company and external responsibility is the responsibility of the third party (Lindgren \& Lundgren, 2016).

\section{Conclusions, Implications, Limitations and Suggestions 6.1 Conclusion}

The result of this study describe that auditors must be give pay attention to their roles and responsibilities for their job results. In addition, auditor should be follow the rule of audit regulation.

\subsection{Implications}

The findings of this study can be useful for regulators, auditors, and the company. For regulators, these findings will help in the assessment of initiatives to combat fraud. For auditors, the findings will highlight whether the cases occurred in the Big Four or non-Big Four in order to minimize the impact of financial or non-financial for the country. For the company, This research contributes to the understanding to be more aware of the importance of fraud risk assessment.

\subsection{Limitations and Suggestions}

The main limitation of this study is less vast area of research because of the limited number of reported cases of FFR. There is a possibility that some of the companies involved in the FFR may not yet be detected or disclosed publicly. Moreover, not all respondents give honest and complete information. In addition, the auditor often blamed on fraud cases that arise, when in fact there are several parties who may have acted negligently and thereby simultaneously causing financial losses. Thus, more emphasis needs regulation concerning auditor liability.

\section{References}

[1] ACFE. (2018). Report To The Nations (pp. 1-80). Retrieved from ACFE website: https://s3-uswest2.amazonaws.com/acfepublic/2018-report-to-the-nations.pdf 
[2\} Burton, F. G., Wilks, T. J., \& Zimbelman, M. F. (2013). How Auditor Legal Liability Influences the Detection and Frequency of Fraudulent Financial Reporting. American Accounting Association, 7(2), 915. https://doi.org/10.2308/ciia-50566

[3] Chung, J., Farrar, J., Puri, P., \& Thorne L. (2010). Auditor Liability to Third Parties After SarbanesOxley: An International Comparison of Regulatory and Legal Reforms. Journal of International Accounting, Auditing and Taxation, 19, 66-78.

[4] Dellaportas, S. (2013). Conversations With Inmate Accountants: Motivation, Opportunity and The Fraud Triangle. Accounting Forum, 37(1), 29-39. https://doi.org/10.1016/j.accfor.2012.09.003

[5] DeZoort, F. T., \& Harrison, P. D. (2018). Understanding Auditors' Sense of Responsibility for Detecting Fraud Within Organizations. Journal of Business Ethics, 149(4), 857-874. https://doi.org/10.1007/s10551-016-3064-3

[6] Free, C. (2015). Looking Through The Fraud Triangle: A Review and Call For New Directions. Meditari Accountancy Research, 23(2), 175-196. https://doi.org/10.1108/MEDAR-02-2015-0009

[7] Hogan, C. E., Rezaee, Z., Riley, R. A., \& Velury, U. K. (2008). Financial Statement Fraud: Insights From The Academic Literature. AUDITING: A Journal of Practice \& Theory, 27(2), 231-252. https://doi.org/10.2308/aud.2008.27.2.231

[8] Huang, S. Y., Lin, C.-C., Chiu, A.-A., \& Yen, D. C. (2016). Fraud Detection Using Fraud Triangle Risk Factors. Information Systems Frontiers, 19(6), 1343-1356. https://doi.org/10.1007/s10796-0169647-9

[9] Lau, C. K., \& Ooi, K. W. (2016). A Case Study on Fraudulent Financial Reporting: Evidence From Malaysia. Accounting Research Journal, 29(1), 4-19. https://doi.org/10.1108/ARJ-11-2013-0084

[10] Lindgren, L., \& Lundgren, C. (2016). A Study on Auditor Liability in Sweden. JÖNKÖPING.

[11] Lisic, L. L., Silveri, S. (Dino), Song, Y., \& Wang, K. (2015). Accounting Fraud, Auditing, and The Role of Government Sanctions in China. Journal of Business Research, 68(6), 1186-1195. https://doi.org/10.1016/j.jbusres.2014.11.013

[12] OJK. (2018). Siaran Pers OJK Kenakan Sanksi Terhadap Akuntan Publik dan Kantor Akuntan Publik Auditor PT Sunprima Nusantara Pembiayaan (No. SP 62/DHMS/OJK/X/2018). Retrieved from https://www.ojk.go.id/id/berita-dan-kegiatan/siaran-pers/Documents/Pages/Siaran-Pers-OJK-Kenakan-

Sanksi-terhadap-Akuntan-Publik-dan-Kantor-Akuntan-Publik-Auditor-PT-Sunprima-Nusantara-

Pembiayaan/Siaran\%20Pers\%20sanksi\%20KAP\%20SNP\%20final.pdf

[13] Othman, R., Aris, N. A., Mardziyah, A., Zainan, N., \& Amin, N. M. (2015). Fraud Detection and Prevention Methods in The Malaysian Public Sector: Accountants' and Internal Auditors' Perceptions. Procedia Economics and Finance, 28, 59-67. https://doi.org/10.1016/s2212-5671(15)01082-5

[14] Peraturan BAPEPAM Nomor Kep-36/PM/2003. (n.d.). Kewajiban Penyampaian Laporan Keuangan Berkala.

[15 \} Peraturan Bursa Efek Jakarta (BEJ) Nomor Kep-306/BEJ/07-2004. (n.d.). Kewajiban Penyampaian Informasi.

[16] Priantara, D. (2017, March 5). SEC Bongkar Fraud Akuntansi Homex dengan Pencitraan Satelit. Warta Ekonomi. Retrieved from https://www.wartaekonomi.co.id/read132740/sec-bongkar-fraudakuntansi-homex-dengan-pencitraan-satelit.html

[17] Samsonova-Taddei, A., \& Humphrey, C. (2014). Risk and The Construction of a European Audit Policy Agenda: The Case of Auditor Liability. Accounting, Organizations and Society, 41, 55-72. https://doi.org/10.1016/j.aos.2014.08.002

[18] Sugianto, D. (2018, May 3). OJK Mulai Periksa Laporan Keuangan Bank Bukopin yang Dipermak. detikcom. Retrieved from https://finance.detik.com/moneter/d-4002904/ojk-mulai-periksa-laporankeuangan-bank-bukopin-yang-dipermak 